\title{
A Review on the Progress of Ion-Engineered Water Flooding
}

\author{
Alibi Kilybay, Bisweswar Ghosh, and Nithin Chacko Thomas
}

The Petroleum Institute, Abu Dhabi, UAE

Correspondence should be addressed to Nithin Chacko Thomas; nicthomas@pi.ac.ae

Received 31 July 2016; Revised 17 October 2016; Accepted 27 October 2016; Published 13 February 2017

Academic Editor: Andrea Franzetti

Copyright (C) 2017 Alibi Kilybay et al. This is an open access article distributed under the Creative Commons Attribution License, which permits unrestricted use, distribution, and reproduction in any medium, provided the original work is properly cited.

\begin{abstract}
In the oil and gas industry, Enhanced Oil Recovery (EOR) plays a major role to meet the global requirement for energy. Many types of EOR are being applied depending on the formations, fluid types, and the condition of the field. One of the latest and promising EOR techniques is application of ion-engineered water, also known as low salinity or smart water flooding. This EOR technique has been studied by researchers for different types of rocks. The mechanisms behind ion-engineered water flooding have not been confirmed yet, but there are many proposed mechanisms. Most of the authors believe that the main mechanism behind smart water flooding is the wettability alteration. However, other proposed mechanisms are interfacial tension (IFT) reduction between oil and injected brine, rock dissolution, and electrical double layer expansion. Theoretically, all the mechanisms have an effect on the oil recovery. There are some evidences of success of smart water injection on the field scale. Chemical reactions that happen with injection of smart water are different in sandstone and carbonate reservoirs. It is important to understand how these mechanisms work. In this review paper, the possible mechanisms behind smart water injection into the carbonate reservoir with brief history are discussed.
\end{abstract}

\section{Introduction}

The relatively new EOR technique of tuning the ionic composition of the injecting brine is referred to in this article as "ionengineered water flooding." However, it is more popularly known as "low salinity water flooding" and in different publications it is defined differently, such as "Designer Water Flood" by Shell [1], "Advanced Ion Management $\left(\mathrm{AIM}^{\mathrm{SM}}\right)$ " by ExxonMobil [2], "Low Salinity Water Flood (LoSal $\left.{ }^{\mathrm{TM}}\right)$ " by BP [3] and "Smart Water Flooding" by several authors in recently published articles [4]. In recent years significant attention has been given to many research studies that have been conducted to investigate the effect of low salinity water flooding in both sandstone and carbonate rocks. But the main challenge for the researchers is to define the dominant mechanism behind the improved oil recovery by low salinity water. So far, none of the mechanisms suggested have proven to be dominant, but in many studies strong arguments were provided by the authors to support the mechanism based on their experimental findings.

Wettability alteration by ionic activity on the rock surface as a possible mechanism behind improved oil recovery by low salinity water flooding has found greater support compared to other possible mechanisms. However, other possible mechanisms such as IFT reduction, electric double layer expansion, and rock dissolution are also found to have contribution in releasing trapped oil in laboratory investigation. The objective of this review is to define the mechanisms behind low salinity water both in sandstone and carbonate rocks based on the published data.

\section{Early Studies on Low Salinity Water Flooding}

The first study on the effect of reduced salinity on water flood oil recovery was performed by Bernard [5], in which he reported the effect of saline water and fresh water on oil recovery in core plugs containing hydratable clays. From this study, the author concluded that more oil was recovered from fresh water flooding than from brine flooding. According to the author, higher oil recovery from fresh water flooding was due to two mechanisms. First, the clay swelling in contact with fresh water, which leads to squeezing of the oil out of the pores; and second is the fines migration as a result of dispersed clays attached with the fine oil droplets. The migration of fines causes plugging of flow channels which 
may alter or create new channels. The proposed mechanism was explained by several core flood experiments, using fresh water and brine separately as well as by sequential injection, to investigate the effect of salinity on clay swelling and migration.

After a gap of few decades, Tang and Morrow [6] initiated studies on the effect of salinity of injected brine and temperature on the wettability of the rock and oil recovery. From results of imbibition experiments, they found that, for crude oil, brine, and rock interactions, the more diluted the brine, the slower the initial recovery and higher the final oil recovery. Increase in oil recovery by decreasing brine salinity was observed for water flooding experiments as well. The same conclusion of slow recovery at initial stage of flooding and higher recovery from final flooding of low salinity brine was made by Zhang and Morrow [7]. Another important observation was the strong impact of rock wettability on oil recovery. The recovery efficiency of low salinity water in sandstone reservoirs is demonstrated by laboratory experiments of several other researchers such as Morrow et al. [8], Morrow et al. [9], Zhang and Morrow [7], and Agbalaka et al. [10]; all of them came to the conclusion that, by decreasing the salinity of injected brine, the oil recovery factor could be enhanced.

The possible mechanisms of low salinity water work differently in sandstone and carbonate rocks. Austad et al. [11] gave a detailed description on the microscopic activities occurring when low salinity water is injected to sandstone reservoirs. Though it was assumed that the wettability alteration is the main reason for low salinity water effect, other mechanisms suggested by different investigators are not ruled out. The possible mechanisms suggested by various authors are fines migration, fluid flow due to osmotic pressure caused by salinity gradients, $\mathrm{pH}$ increase, multicomponent ion exchange (MIE), and electric double layer expansion, in addition to the contribution from IFT reduction.

According to Austad et al., when low salinity water is injected into the reservoir, the initial chemical equilibrium in the reservoir is disturbed and $\mathrm{Ca}^{2+}$ ions are replaced by $\mathrm{H}^{+}$ions which leads to an increase in $\mathrm{pH}$ of the system. This phenomenon is due to the high attraction of $\mathrm{H}^{+}$ions towards the clay surface. With desorption of cations from clay surface the polar components of oil which are attached to reservoir minerals will also be removed from the clay surface since it is very sensitive to $\mathrm{pH}$ changes. The concentration changes of $\mathrm{Mg}^{2+}$ and $\mathrm{Ca}^{2+}$ with changes in the brine $\mathrm{pH}$ are also observed in these experiments.

However, Lager et al. [3] concluded from geochemical analysis of the core flood effluent that, during injection of low salinity water into the carbonate formation, the polar compounds of oil will be detached from the rock surface and replaced by cations such as $\mathrm{Mg}^{2+}$ and $\mathrm{Ca}^{2+}$. This activity is related to multicomponent ion exchange (MIE) that causes the wettability alteration of the rock. Another conclusion from their research is that the increase in oil recovery is not related to an increase in $\mathrm{pH}$, because of some evidences from other studies showing improved oil recovery at lower $\mathrm{pH}$ [24]. Lager et al. [25] further confirmed that MIE is a responsible mechanism of increase in oil recovery on the field scale. The oil recovery increased dramatically by injection of low salinity water. Produced water showed total removal of $\mathrm{Mg}^{2+}$ from the injected water which proved strong interaction in the brine/rock system.

\section{Low Salinity Water Flooding in Carbonate Rocks}

There has been increasing interest among researchers in applying smart water flooding in carbonate reservoirs for oil recovery as significant amount of oil reserves are located in carbonate rocks. Low operational and capital expenditure of water flooding process plays major role as well. Oil recovery in carbonate rocks however is more challenging than in sandstone reservoirs due to higher level of heterogeneity and complexity of the reservoir structure. Understanding the ionic interaction between low salinity water and carbonate rocks is more complex since most of the carbonate reservoirs are more oil wet than water wet. Moreover, compared to sandstone reservoirs, fewer researches have been done on LSW in carbonate rocks and very few field trials have been conducted so far. Below are the possible mechanisms of low salinity water in carbonate rocks, extracted from the available literatures.

3.1. Wettability Alteration. Wettability alteration of the rock surface is stated by many authors as a dominating mechanism behind improved oil displacement efficiency by low salinity water injection [3]. The main reason for altering the wetting surface of the rock surface is the multicomponent ionic exchange. In carbonate rocks, the potential determining ions such as $\mathrm{Ca}^{2+}, \mathrm{Mg}^{2+}$, and $\mathrm{SO}_{4}{ }^{2-}$ are the driving ions in changing the wettability as shown in Figure 1 [22]. The divalent anion $\mathrm{SO}_{4}{ }^{2-}$ present in formation water competes with carboxylic acid of crude oil, which is attached to the rock surface. This behavior of ions leads to detachment of acid groups from the carbonate surface, thus changing the rock wettability. In order to work properly in such an environment, anions require divalent cations and vice versa [12].

A research study on better understanding the effect of brine composition on displacement efficiency and wettability alteration mechanism of low salinity water in Middle East carbonate rocks was conducted by Yi and Sarma [13] at different temperature ranges from $70^{\circ} \mathrm{C}$ to $120^{\circ} \mathrm{C}$. From laboratory experiments they concluded that, at $70^{\circ} \mathrm{C}$, lowering of the brine salinity resulted in more oil recovery than increasing the $\mathrm{SO}_{4}{ }^{2-}$ concentration. Similar activity was observed at $120^{\circ} \mathrm{C}$. The whole experiment was found to be sensitive to temperature variation. LSW with high concentration of $\mathrm{SO}_{4}{ }^{2-}$ ions showed better recovery at $120^{\circ} \mathrm{C}$ than at $70^{\circ} \mathrm{C}$. From spontaneous imbibition tests at $90^{\circ} \mathrm{C}$, the wettability is seen to change more towards water wet, by both decreasing the brine salinity and increasing the $\mathrm{SO}_{4}{ }^{2-}$ concentration of surrounding water. However, the divalent cations responded less on wettability alteration than monovalent cations. Overall, the conclusion was that the wettability alteration and fines migration are the main mechanisms of low salinity water. 

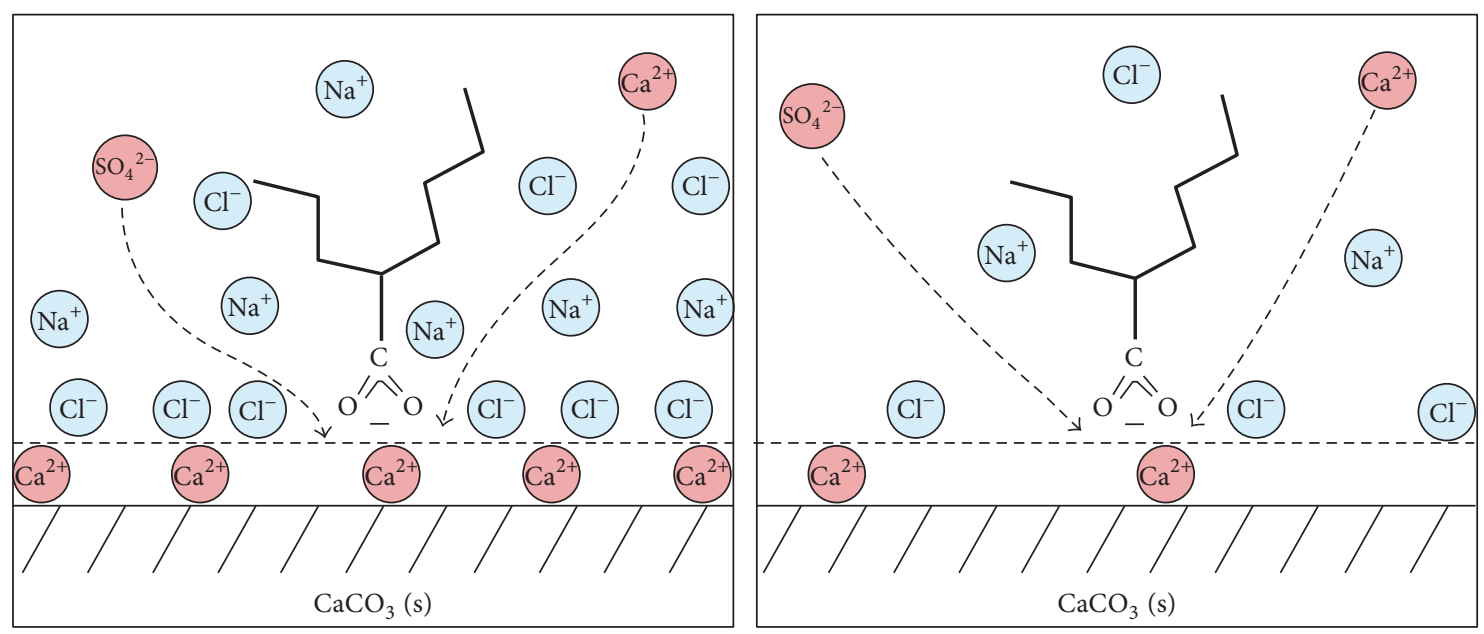

FIGURE 1: Schematic of wettability alteration principle by injecting sea water [22].

Most of the authors supported multicomponent ion exchange as one of the dominating mechanisms governing smart water flooding $[7,14,15]$. Yi and Sarma [13] concluded that MIE's concept in carbonate reservoirs is similar to that in sandstone reservoirs. In sandstone rocks the cation exchange happens in rock/brine/oil systems; however in carbonate rocks it is an anionic exchange between rock and brine (Figure 1). In carbonate rocks, MIE works mainly due to the PDIs or potential determining ions $\left(\mathrm{Ca}^{2+}, \mathrm{Mg}^{2+}\right.$, and $\left.\mathrm{SO}_{4}{ }^{2-}\right)$. The rock surface adsorbs $\mathrm{SO}_{4}{ }^{2-}$, which is also coadsorbed by $\mathrm{Ca}^{2+}$ and $\mathrm{Mg}^{2+}$ ions, while carboxylic acids desorb from rock surface as potential determining ions (PDIs) replace them. As a result of this ionic exchange, the rock surface will turn to a more water wet state. According to the aforementioned authors, during this process on the rock surface, sulfate reduced the electrostatic repulsive force and acted as a catalyst, by helping $\mathrm{Ca}^{2+}$ and $\mathrm{Mg}^{2+}$ ions to adsorb to the rock surface. At high temperature, $\mathrm{Mg}^{2+}$ ions possibly replace the $\mathrm{Ca}^{2+}$ ions of the rock surface that is bounded with carboxylic group. In this process, the organometallic group could also be displaced. Due to this ionic behavior on the rock surface, the rock wettability changes to less oil wet because of the released oil components. The schematic of MIE on wettability alteration of the carbonate rock can be seen in Figure 2, which depicts oil recovery and pressure drop in core flooding experiment at reservoir conditions with increasing pore volume of various injected brines. The secondary recovery stage with formation water injection recovered $68.43 \%$ of OOIP, while SW and CaMg4S brine recovered $7.47 \%$ and $18.66 \%$ additional oil, respectively. From this experiment it is concluded that the PDI's effect on oil recovery is significant. Hognesen et al. [26] also concluded that, at high temperature, $\mathrm{SO}_{4}{ }^{2-}$ concentration plays significant role in increasing oil recovery due to its ability to modify the wetting nature of the carbonate rocks. The special role of $\mathrm{SO}_{4}{ }^{2-}$ on oil recovery was confirmed by Strand et al. [15]. The study included spontaneous imbibition comparing sea water with and without sulfate ion. Sulfate free sea water injection resulted in 15\% less oil recovery than sea water with sulfate.

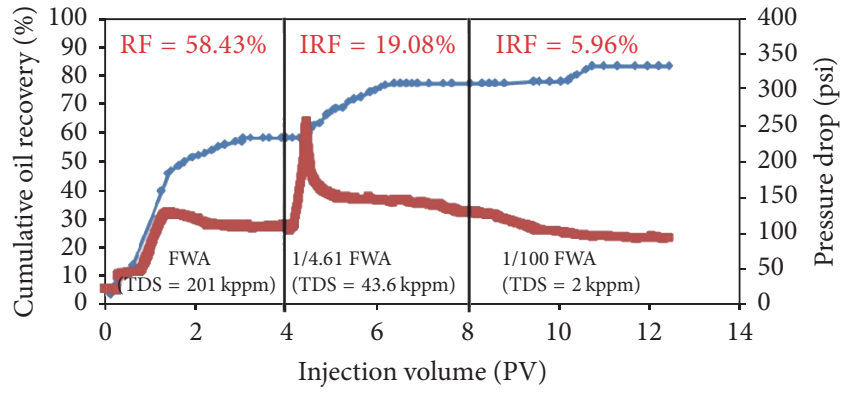

FIGURE 2: Cumulative oil recovery and pressure difference curves with respect to pore volume injected [13].

One of the first studies on carbonate rocks to evaluate the effect of brine composition was conducted by Yousef et al. [4]. From their laboratory investigations it was concluded that the wettability of the rock surface is a strong function of the salinity and ionic composition of the injected brine (Table 1). From contact angle measurements they found that, by diluting the sea water, the rock surface becomes more water wet and it might be a good reason for improved oil recovery. Significant reduction of contact angle to around $69^{\circ}$ was observed by injecting 10 times diluted sea water. By performing NMR studies, they concluded that dilution of sea water changes the surface charge of the rocks significantly and the resulting interaction between brine and rock leads to wettability alteration. This conclusion from NMR studies is the confirmation of the previous work of Yousef et al. [18]. In this work, they observed faster surface relaxation time (T2) with injection of different salinity brines. This is due to the change in wettability of the rock which is confirmed from contact angle measurements. As a main experiment to define the oil recovery on different salinities, the authors performed core flooding in sequential order by decreasing the salinity and its result is given in Figure 3. After secondary flooding with sea water, they flooded the core with diluted sea water. As the salinity of the brine decreased, the incremental oil recovery was observed to increase up to $18 \%$ additional 
TABLE 1: Summary of the investigation.

\begin{tabular}{|c|c|c|c|c|}
\hline & Proposed mechanism & Reference & $\begin{array}{l}\text { Experiments } \\
\text { conducted }\end{array}$ & Conclusions drawn \\
\hline 1 & $\begin{array}{l}\text { Clay swelling and } \\
\text { fines migration }\end{array}$ & Bernard [5] & Core flooding & $\begin{array}{l}\text { Migration of fines plugs the flow channels } \\
\text { and creates new channels. Profile } \\
\text { modification on pore scale. Also clay } \\
\text { swelling which squeezes out oil from } \\
\text { pores. }\end{array}$ \\
\hline 2 & Wettability alteration & $\begin{array}{l}\text { Tang and Morrow [6]; } \\
\text { Zhang and Morrow } \\
{[7]}\end{array}$ & $\begin{array}{l}\text { Imbibition test and } \\
\text { core flooding }\end{array}$ & $\begin{array}{l}\text { More diluted brine, the oil recovery being } \\
\text { slower at initial stage and higher at final } \\
\text { stage. }\end{array}$ \\
\hline 3 & Various & $\begin{array}{l}\text { Morrow et al. [8]; } \\
\text { Morrow et al. [9]; } \\
\text { Zhang and Morrow } \\
\text { [7]; Agbalaka et al. } \\
\text { [10] }\end{array}$ & Core flooding & $\begin{array}{l}\text { With decreasing salinity, oil recovery } \\
\text { increases. }\end{array}$ \\
\hline 4 & $\begin{array}{l}\text { Fines migration, MIE, } \\
\text { EDL expansion }\end{array}$ & Austad et al. [11] & $\begin{array}{l}\text { Zeta Potential Studies } \\
\text { \& Adsorption } \\
\text { measurements }\end{array}$ & $\begin{array}{l}\text { Initial chemical equilibrium is disturbed } \\
\text { when LSW injected into the reservoir, } \\
\text { which leads to detachment of oil from } \\
\text { clay surface. }\end{array}$ \\
\hline 5 & $\begin{array}{l}\text { Wettability alteration, } \\
\text { MIE }\end{array}$ & $\begin{array}{l}\text { Lager et al. [3]; } \\
\text { Mohanty and } \\
\text { Chandrasekhar [12] }\end{array}$ & Core flooding & $\begin{array}{l}\text { PDIs are the deriving ions in changing } \\
\text { the wettability }\end{array}$ \\
\hline 6 & $\begin{array}{l}\text { Wettability alteration, } \\
\text { fines migration }\end{array}$ & Yi and Sarma [13] & $\begin{array}{l}\text { Core flooding, } \\
\text { spontaneous } \\
\text { imbibition }\end{array}$ & $\begin{array}{l}\text { Rock can become more water wet by } \\
\text { decreasing the salinity of brine or } \\
\text { increasing the } \mathrm{SO}_{4}{ }^{2-} \text { concentration. PDIs } \\
\text { desorb carboxylic acids from rock } \\
\text { surface. }\end{array}$ \\
\hline 7 & $\begin{array}{l}\text { Wettability alteration, } \\
\text { MIE }\end{array}$ & $\begin{array}{l}\text { Austad et al. [14]; } \\
\text { Strand et al. [15]; } \\
\text { Zhang and Morrow } \\
\text { [7] }\end{array}$ & $\begin{array}{l}\text { Contact angle } \\
\text { measurements }\end{array}$ & $\begin{array}{l}\text { MIE is the main mechanism behind } \\
\text { increased oil recovery from low salinity } \\
\text { water flooding. }\end{array}$ \\
\hline 8 & Wettability alteration, & Yousef et al. [4] & $\begin{array}{l}\text { Contact angle } \\
\text { measurements, NMR } \\
\text { studies. core flooding }\end{array}$ & $\begin{array}{l}\text { Rock surface become more water wet by } \\
\text { diluting injected sea water, } 18 \% \text { additional } \\
\text { oil recovery after secondary stage with } \\
\text { sea water. }\end{array}$ \\
\hline 9 & $\begin{array}{l}\text { Wettability } \\
\text { modification }\end{array}$ & Romanuka et al. [16] & $\begin{array}{l}\text { Capillary imbibition } \\
\text { test }\end{array}$ & $\begin{array}{l}\text { Higher oil recovery from injection of } \\
\text { lower ionic strength brine. }\end{array}$ \\
\hline 10 & Wettability alteration & Al Quraishi et al. [17] & $\begin{array}{l}\text { Core flooding, zeta } \\
\text { potential and contact } \\
\text { angle studies }\end{array}$ & $\begin{array}{l}17 \% \text { additional oil recovery after tertiary } \\
\text { flooding with sea water. Contact angle } \\
\text { dropped from } 102^{\circ} \text { to } 70^{\circ} \text { with } 10 \text { times } \\
\text { diluted sea water. }\end{array}$ \\
\hline 11 & Rock dissolution & Yousef et al. [18] & $\begin{array}{l}\text { Core flooding, Zeta } \\
\text { potential, NMR }\end{array}$ & $\begin{array}{l}\text { Lowering Ca concentration of injected } \\
\text { brine leads to calcium carbonate } \\
\text { dissolution. As a result, the polar } \\
\text { components of oil would be released } \\
\text { from rock surface. }\end{array}$ \\
\hline 12 & & Mahani et al. [19] & $\begin{array}{l}\text { Zeta-potential } \\
\text { measurements, } \\
\text { ICP-MS }\end{array}$ & $\begin{array}{l}\text { With increasing } \mathrm{pH} \text {, zeta potential is } \\
\text { towards positive and with increasing } \\
\text { salinity has less influence. Mineral } \\
\text { dissolution exists with } 25 \text { times diluted } \\
\text { SW. }\end{array}$ \\
\hline 13 & $\begin{array}{l}\text { Electric double layer } \\
\text { effect }\end{array}$ & $\begin{array}{l}\text { Ligthelm et al. [1]; } \\
\text { Nasralla and } \\
\text { Nasr-EL-Din }[20,21]\end{array}$ & Zeta potential studies & $\begin{array}{l}\text { By decreasing the } \mathrm{pH} \text { of LSW, the electric } \\
\text { charges of oil/brine and rock/brine } \\
\text { surfaces changed from highly negative to } \\
\text { close to zero value, which means that the } \\
\text { expansion of EDL was reduced. }\end{array}$ \\
\hline 14 & IFT reduction & Yousef et al. [4] & IFT studies & $\begin{array}{l}\text { Salinity of injected brine has minor } \\
\text { impact on the IFT and fluid-fluid } \\
\text { interactions. }\end{array}$ \\
\hline
\end{tabular}


TABle 1: Continued.

\begin{tabular}{|c|c|c|c|c|}
\hline & Proposed mechanism & Reference & $\begin{array}{l}\text { Experiments } \\
\text { conducted }\end{array}$ & Conclusions drawn \\
\hline 15 & & Al Quraishi et al. [17] & IFT studies & $\begin{array}{l}\text { By diluting the brine up to } 10 \text { times, the } \\
\text { interfacial tension between oil and brine } \\
\text { reduced to only } 6 \text { units which is } \\
\text { insignificant. }\end{array}$ \\
\hline
\end{tabular}

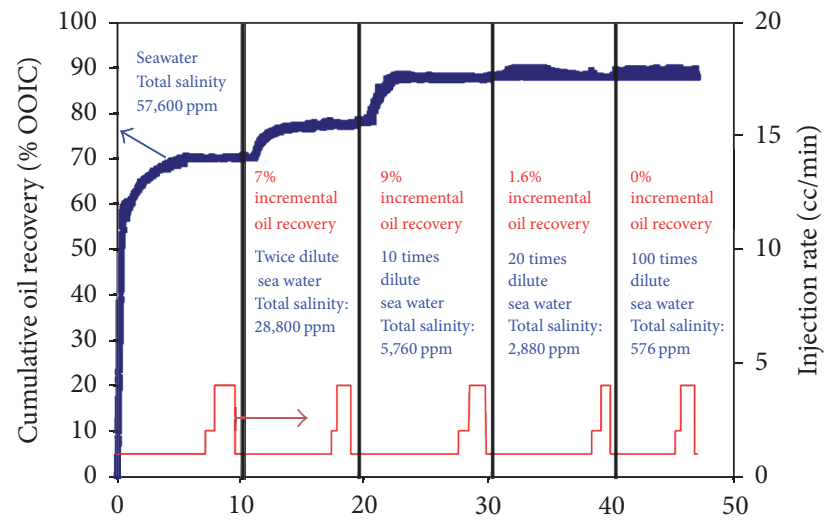

FIGURE 3: Oil recovery curve of the core flooding experiment [18].

recovery beyond sea water recovery. Therefore, the salinity and ionic composition of the brine has significant effect on brine/rock/oil interaction, wettability, and microscopic displacement efficiency. Another core flooding experiment was conducted by the author in order to study the effect of dilution of sea water. After plain sea water injection, injection of two times and ten times diluted sea water resulted in significant oil recovery ( $7 \%$ and $9 \%$ of OOIP, resp.). However, twenty times diluted sea water and hundred times diluted sea water injection resulted in $1.6 \%$ and $0 \%$ additional oil recovery.

Romanuka et al. [16] presented the results of the screening experiments of low salinity water on different carbonate rocks through capillary imbibition tests in Amott cells. The oil production was compared between formation water and wettability modifying brines where ionic compositions and ionic strengths were altered. Higher oil recovery was observed by injecting lower ionic strength brine. The authors performed wettability modification with two approaches: by increasing the concentration of surface interacting ions $\left(\mathrm{SO}_{4}{ }^{2-}, \mathrm{BO}_{3}{ }^{3-}\right.$ or $\mathrm{PO}_{4}{ }^{3-}$ ) and by lowering the ionic strength of brines. The results indicated that, by lowering the ionic strength of the brine, the oil recovery can be increased in carbonate rocks. This behavior is possibly due to the wettability alteration towards more water wetness.

Al-Harrasi et al. [27] conducted laboratory experiments on LSW effect on carbonate rocks through spontaneous imbibition and core flooding experiments. They used brines with different dilutions of formation water from two to hundred times in their experiments. All of these brines improved the oil recovery. From spontaneous imbibition, as the salinity of brine is reduced, the oil recovery increased with highest recovery observed for hundred times diluted brine. These results let the authors to believe that low salinity water leads to wettability alteration. Another experiment was conducted to study that the effect of LSW is core flooding. In order to avoid capillary end effect and lowering IFT between oil and brine, they first flooded the core with high salinity water at high flow rate and then switched to low salinity brine. The results of the flooding tests showed 3-5\% increase in recovery after injection of one pore volume of low salinity brine. From IFT studies, the authors found that there was a little change in IFT between brines and oil which cannot be considered as a significantly contributing mechanism of LSW. They concluded that, from experiments of spontaneous imbibition and core flooding, the wettability alteration is the main mechanism for improved oil recovery by LSW in carbonate rocks.

A research study on low salinity water injection with different values of salinity and concentration of $\mathrm{SO}_{4}{ }^{2-}$ and $\mathrm{Ca}^{2+}$ ions on carbonate rocks was conducted by Al-Attar et al. [28]. Using the cores, sea water and injection water from Middle East region in a flooding unit, they found that, with decreasing salinity, the oil recovery increased dramatically up to $84 \%$ OOIP. Then, to study the effect of different ion compositions they used the most promising salinity brine. First, they saturated the brine with different concentrations of $\mathrm{SO}_{4}{ }^{2-}$. From $\mathrm{SO}_{4}{ }^{2-}$ concentration studies, they concluded that, with increasing sulfate concentration in the brine, more oil recovery was observed up to the critical saturation above which the recovery decreases. By increasing the sulfate concentration up to four times, the oil recovery increased up to $87.2 \%$ OOIP, while the brine with six times sulfate resulted in oil recovery $61.5 \%$ OOIP. However, with increasing calcium concentration, they observed a reduction in oil recovery which means that calcium ions might have some negative effect. To establish the possible mechanism for improving oil recovery, the authors conducted several other experiments. Contact angle studies suggest that, with decreasing salinity, the rock surface wettability tends to change to more mixed wet state. Interestingly, from this study the authors could not state any correlation between IFT and oil recovery, which means that the change in IFT does not affect the oil recovery much. The same conclusion has been made for $\mathrm{pH}$ values, stating that there is no correlation between different $\mathrm{pH}$ values and oil recovery. Also they compared the performance of composite core flooding, which indicated that there is a good match with short core plugs which means that the results can be applied to field scale.

Alameri et al. [29] conducted laboratory studies on the effect of low salinity water on oil recovery with and without 
surfactant. Whole experimental studies consisted of core flooding apparatus, ultrafast centrifuge, and contact angle apparatus to determine the possible mechanisms of low salinity water in carbonate rocks. The core flooding experiments showed that omitting $\mathrm{NaCl}$ from sea water increased oil recovery by $8 \%$ and by diluting the sea water two and four times, oil recovery resulted in $6.0 \%$ and $1.1 \%$ additional oil recovery, respectively. From contact angle studies, they found that with the reduction of salinity both aged and unaged carbonate rock surface became more water wet both with and without the surfactant addition.

Al Quraishi et al. [17] conducted several experiments on low salinity water in carbonate reservoirs including core flooding, zeta potential, and contact angle studies. The core flooding studies as a tertiary recovery process resulted in $17 \%$ OOIP recovery by diluting the brine up to 10 times after $64 \%$ oil recovery from secondary flooding. The core flooding studies as a secondary recovery resulted in $74 \%$ OOIP cumulative recovery by ten times diluted SW while flooding with sea water alone showed $64 \%$ OOIP recovery. Increase in oil recovery by low salinity water flooding was explained by the authors as a result of wettability alteration. From contact angle measurements they found that the wettability of the rock surface changes towards more water wet condition. In the presence of formation water, the contact angle was $102^{\circ}$, which is intermediate wet. The sea water and twice diluted sea water showed slight changes of contact angel to $98^{\circ}$ and $95^{\circ}$, respectively. However, the most significant change towards water wet condition was observed with 10 times diluted sea water and the contact angle dropping to $70^{\circ}$. In order to enlarge the understanding of the mechanism behind low salinity water in carbonate rocks, the authors performed zeta potential studies. By diluting and changing the ionic composition of brines, the overall surface charge approaches more negative value, with significant negative charge at 10 times diluted sea water. From the explanation of the author, the results from core flooding, contact angle, and zeta potential experiments are strongly related to wettability change of carbonate rock surface from intermediate to more water wet surface.

The effect of individual PDIs $\left(\mathrm{Ca}^{2+}, \mathrm{Mg}^{2+}\right.$, and $\left.\mathrm{SO}_{4}{ }^{2-}\right)$ together with other common ions such as $\mathrm{Na}^{+}$and $\mathrm{Cl}^{-}$on carbonate rocks was studied by Kwak et al. [30]. This research was performed by NMR (Nuclear Magnetic Resonance) studies to see the chemical and physical behaviors of brine and rock surface only and oil/brine/rock interactions were not included. The results from brine/rock interaction studies are useful in multiphase studies on oil/brine/rock interactions. From experimental works, the authors stated that, among three PDIs, $\mathrm{Mg}^{2+}$ and $\mathrm{SO}_{4}{ }^{2-}$ ion's reactivity is stronger than $\mathrm{Ca}^{2+}$ ion's reactivity. When these ions come into contact with the formation, the surface relaxivity on NMR changes due to the rock/brine interaction. Individual input of these three ions differs on NMR T2 response. When $\mathrm{Ca}^{2+}$ and $\mathrm{Mg}^{2+}$ ions adsorb on the rock surface, the total surface charge shows little change from negative to positive. Because of this behavior, the electrical potential of the rock surface increases; thus more water molecules bind to paramagnetic ions $\left(\mathrm{Mn}^{2+}\right.$ and $\mathrm{Fe}^{3+}$ ) of carbonate rock surface. Because of the increase in water molecules on the rock surface, T2 distribution shows shorter time. When $\mathrm{SO}_{4}{ }^{2-}$ ion gets adsorbed on the rock surface, most paramagnetic ions of carbonate rocks get bounded to them. Therefore, it causes a barrier for water molecules to be attached on the rock surface, consequently, decreasing the number of water molecules that relax at the rock surface. As a result of such ionic behavior on the rock surface, $T 2$ distribution of water in carbonate rocks shows longer time, which means less water molecules attached to the rock surface. So, when all PDIs come into reaction with carbonate rocks, $T 2$ distribution will depend on the change of total surface charge and the availability of paramagnetic ions.

3.2. Rock Dissolution. Rock dissolution by injecting low salinity water into the reservoir rock significantly affects the oil recovery as observed by several investigators [18]. By lowering the calcium concentration of the brine in carbonate rocks, the equilibrium within brines can be disturbed which may lead to calcium carbonate dissolution; as a result of that, the polar components of the oil could be released from rock surface and change in wettability of the rock towards more water wet condition may happen. Also, as a result of rock dissolution, dissolved minerals will be transported through the formation and later precipitate and might block some pore throats. When some of the pore throats get blocked, the flow path would change to another flow unit in the reservoir towards nonswept zones and improve the microscopic sweep efficiency. This behavior in the formation is possibly the main mechanism behind improved oil recovery by low salinity water.

Austad and coresearchers in several of their publications suggested that the rock dissolution during low salinity water flooding is a potential mechanism that can contribute to oil recovery. By applying a geochemical model for chalk, they studied the transformation of chalk to other minerals, which developed a correlation between oil recovery and chalk dissolution. Also from this experiment, they found that low salinity water in carbonates works by decreasing the calcium concentration in produced brine. This change causes calcium carbonate dissolution to establish equilibrium within brines. It is a proven phenomenon that the polar components of oil will be released from the rock surface as a result of rock mineral dissolution.

Yousef et al. [18] performed laboratory NMR studies to see the effect of ionic composition and salinity of brine on carbonate rock sample. The observation from this work is that the fast relaxing micropores and slow relaxing micropores are overlapped. This behavior is called pore coupling in NMR, which might be because of the connectivity between microand macropores that is enlarged as a result of microscopic dissolution caused by injected brine low in $\mathrm{CaCO}_{3}$. The salinity and ionic composition of initial water in the reservoir are changed with the presence of injected brine.

Recently Mahani et al. [19] conducted a detailed study to understand the mechanism of LSW and possibility of calcite dissolution as a mechanism for improved oil recovery. The study was conducted on zeta potential measurements to see the solid-liquid interaction and contact angle measurements 
to see the wettability change on limestone and dolomite rocks. Their findings show that, with increasing $\mathrm{pH}$, zeta potential gets more positive and with increasing salinity zeta potential gets less influenced by brine. This might be because the PDIs get attracted to the rock surface even more strongly since the PDIs concentrations are more in sea water (SW) than in formation water (FW). From experimental results the authors concluded that low salinity effect (LSE) might exist even without dissolution while the mineralogy of carbonate rock has significant effect on LSE. From contact angle measurements it was seen that the sea water decreases contact angle to more water wet in the absence of mineral dissolution. This is supported by constant $\mathrm{pH}$ of the brines (FW and SW) during the experiment. Moreover, from ICPMS measurements it was clear that the mineral dissolution exists when 25 times diluted SW was equilibrated with carbonate rock. The concentration of $\mathrm{Ca}^{2+}$ and $\mathrm{Mg}^{2+}$ ions in LSW increased while it was decreased in SW due to precipitation. Another interesting finding by the author was the contribution of mineral dissolution to contact angle changes. First, an experiment was performed by $\mathrm{NaCl}$ brine at low $\mathrm{pH}$ where the mineral dissolution capacity of the LSW was enhanced; as a result of that, the contact angle was changed sharply. Next, the mineral dissolution of the brine was suppressed by the equilibration of calcium saturated brine with limestone. The $\mathrm{pH}$ of the brine remained constant and the contact angle changed. This means that the wettability alteration without mineral dissolution can be a possible mechanism of LSW in carbonate rocks.

3.3. Electric Double Layer Effect. The surface of the rock, which has an electrical charge, generates an electrical field when it contacts water and creates two layers on its surface. First, it attracts oppositely charged ions, which are called counter ions, and creates a charged surface. Second, due to the thermal motion, another layer forms by these counter ions which is called a diffuse layer outside the charged surface. These two layers of diffuse and charged surfaces are called electrical double layers (EDL), which establishes an electrical neutral environment [23]. A schematic of electric double layer is given in Figure 4. The electric double layer of ions on the rock surface has a complicated structure which is currently poorly understood. Stern in 1924 [31] performed studies on EDL and defined the first layer of ion which is close to surface as a "Stern Layer."

In the reservoir, the water-film stability and the thickness of EDL are due to electric surface charges at oil and rock interfaces. By injecting the low salinity water into the formation, the electrical charges at oil/brine and rock/brine interfaces will be changed which leads to the change of EDL thickness and water-film stability interruption. The purpose of low salinity water injection is to develop a stable water film which will result in improved oil recovery [21].

Electric double layer is considered as the main mechanism of IOR by some researchers. Ligthelm et al. [1] suggested that electric double layer expansion in sandstone reservoirs is the main contributor of low salinity water flood recovery. Due to the reduction of brine's ionic strength, the wettability tends to change to more water wet state. The research stated that

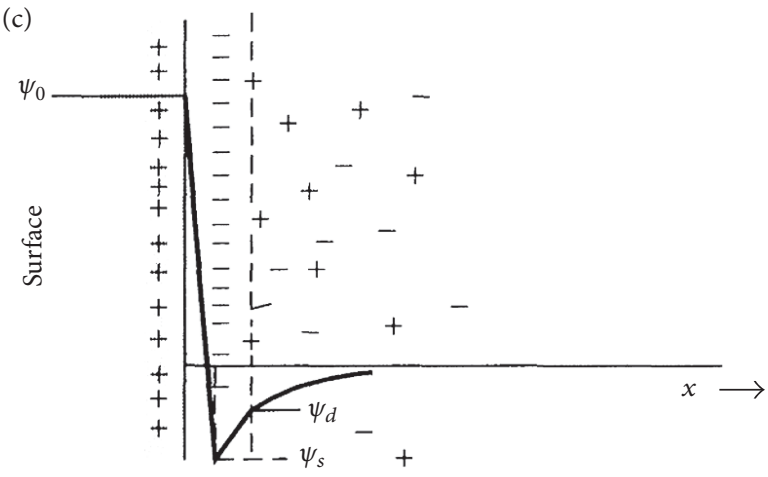

FIGURE 4: Example of electric double layer, where anions strongly attached to positively charged rock surface [23].

the electrical double layer expansion is not the mechanism behind improved oil recovery in carbonate reservoirs. Since the carbonate rock surface is different from sandstone, there is no need for increased electrostatic repulsive forces. Nasralla and Nasr-El-Din [20, 21] performed zeta potential, contact angle, and core flooding studies to investigate the effect of EDL on recovery. By decreasing the $\mathrm{pH}$ of low salinity brine, the electric charges of oil/brine and rock/brine surfaces changed from highly negative to close to zero, which means that the expansion of EDL was reduced. By such behavior, the surface becomes more oil wet, which means oil recovery will be less than low salinity water at normal $\mathrm{pH}$. By correlating zeta potential study results with contact angle and core flooding experiments, the author stated that the EDL might be the dominating mechanism behind increasing the oil recovery in secondary mode.

3.4. IFT Reduction. Most of the researchers agreed that, by changing the ionic composition of injecting brine, the capillary forces in the core will be affected. But with respect to IFT reduction with low salinity water, none could provide strong evidence through laboratory experiments. Yousef et al. [4] performed IFT studies between oil and different brines at reservoir conditions. From these studies the authors concluded that the salinity of injected brine has minor impact on the IFT and fluid-fluid interactions. General trend was that the IFT at oil/brine interface became less when changing the formation water to sea water, and IFT reduction was insignificant when the brines were diluted.

Al Quraishi et al. [17] conducted interfacial tension measurements between oil and different brines using pendent drop tensiometer at reservoir conditions. With decreasing salinity of brines by dilution up to 10 times, the interfacial tension between oil and brine reduced to about 6 units which is not significant enough to be a dominant mechanism for low salinity water flooding.

Zahid et al. [32, 33] carried out experiments on DBR JEFRI Cell to study the oil/brine interaction under different pressures and temperatures for the oil sample from Latin America and Middle East. With increasing sulfate concentration at high temperature, the oil/brine interface showed a 
new phase (probably emulsion) with Middle East oil sample. After PVT Cell, the authors checked the viscosity of the crude oil for different brines. When high pressure and temperature were applied, the oil viscosity decreased with increase in sulfate concentration with Latin American oil sample. This decrease in viscosity of oil phase was explained by the authors as the change in shape of the heavy component's molecules of crude oil, the same that happens when salt is added to polymers solution. However, this mechanism of viscosity reduction of crude oil is not clear yet. Finally, the authors performed core flooding studies, where significant increase in oil recovery was observed by injecting low salinity water at high temperature for Middle East core plugs. The authors concluded that both viscosity reduction and emulsion formation are the possible mechanisms of increased oil recovery by addition of sulfate ions.

\section{Conclusion}

Ion-engineered water flood recovery technique is discussed for both sandstone and carbonate reservoirs. Attention is paid to the possible mechanisms behind this novel method of EOR. As stated by many researchers mentioned above, low salinity water is one of the promising methods of EOR. Therefore, before applying this method at field scale, the mechanisms behind this technique should be clearly understood. As we can see from the summarized papers, several mechanisms are proposed by many authors mentioned above and each of them contributed significantly with different types of laboratory experiments. The mechanisms discussed are as follows:

(1) Wettability alteration: the oil attached to the rock surface is replaced by injected water ions; thus rock becomes more water wet

(2) Rock dissolution: by decreasing the calcium concentration of the injected brine, the ionic equilibrium on the rock surface is disturbed, thus leading to dissolution of $\mathrm{CaCO}_{3}$

(3) Electric double layer effect: PDIs of injected brine stabilizes and expands the ionic two layers on the rock surface. Expansion of EDL squeezes out the oil from the pores

(4) IFT reduction: the microemulsion between oil and injected brine is created due to IFT reduction between these two fluids. Creation of microemulsion makes it easier for injected brine to pull out the oil from pores.

From all of the suggested mechanisms, none has so far been convincing as the main contributor of low salinity water. This uncertainty is due to the complexity of reservoir structures in microscopic scale. However, most of the researchers believe that the main contributor of low salinity water to increase oil recovery is the wettability alteration. The role of PDIs is significant in altering the wetting characteristics of rock from oil wet to more water wet condition. LSW injection in industry is still considered to be an emerging EOR method and needs more studies in both the laboratory and field scales to better understanding of the mechanisms behind this EOR technique.

\section{Competing Interests}

The authors declare that there is no conflict of interests regarding the publication of this paper.

\section{Acknowledgments}

The authors would like to thank The Petroleum Institute for providing the necessary opportunity to conduct this study.

\section{References}

[1] D. J. Ligthelm, J. Gronsveld, J. Hofman, N. Brussee, F. Marcelis, and H. van der Linde, "Novel waterflooding strategy by manipulation of injection brine composition," in Proceedings of the EUROPEC/EAGE Conference and Exhibition, SPE-119835-MS, Amsterdam, The Netherlands, June 2009.

[2] R. Gupta, G. G. Smith, L. Hu et al., "Enhanced waterflood for carbonate reservoirs-impact of injection water composition," in Proceedings of the SPE Middle East Oil and Gas Show and Conference, SPE-142668-MS, Manama, Bahrain, September 2011.

[3] A. Lager, K. J. Webb, I. R. Collins, and D. M. Richmond, "LoSal enhanced oil recovery: evidence of enhanced oil recovery at the reservoir scale," in Proceedings of the SPE Symposium on Improved Oil Recovery, SPE-113976-MS, Tulsa, Okla, USA, April 2008.

[4] A. A. Yousef, S. H. Al-Salehsalah, and M. S. Al-Jawfi, "New recovery method for carbonate reservoirs through tuning the injection water salinity: smart water flooding," in Proceedings of the SPE EUROPEC/EAGE Annual Conference and Exhibition, SPE-143550-MS, Vienna, Austria, May 2011.

[5] G. G. Bernard, "Effect of floodwater salinity on recovery of oil from cores containing clays," in Proceedings of the SPE California Regional Meeting, SPE-1725-MS, Los Angeles, Calif, USA, October 1967.

[6] G. Q. Tang and N. R. Morrow, "Salinity, temperature, oil composition, and oil recovery by waterflooding," SPE Reservoir Engineering, vol. 12, pp. 269-276, SPE-36680-PA, 1997.

[7] Y. Zhang and N. R. Morrow, "Comparison of secondary and tertiary recovery with change in injection brine composition for crude-oil/sandstone combinations," in Proceedings of the SPE/DOE Symposium on Improved Oil Recovery, SPE-99757MS, Tulsa, Okla, USA, April 2006.

[8] N. R. Morrow, M. Valat, and H. Yidliz, "Effect of brine composition on recovery of an alaskan crude oil by waterflooding," in Proceedings of the Annual Technical Meeting, PETSOC-96-94, Calgary, Alberta, June 1996.

[9] N. R. Morrow, G.-Q. Tang, M. Valat, and X. Xie, "Prospects of improved oil recovery related to wettability and brine composition," Journal of Petroleum Science and Engineering, vol. 20, no. 3-4, pp. 267-276, 1998.

[10] C. C. Agbalaka, A. Y. Dandekar, S. L. Patil, S. Khataniar, and J. R. Hemsath, "Coreflooding studies to evaluate the impact of salinity and wettability on oil recovery efficiency," Transport in Porous Media, vol. 76, no. 1, article 77, 2009.

[11] T. Austad, A. Rezaeidoust, and T. Puntervold, "Chemical mechanism of low salinity water flooding in sandstone reservoirs," in Proceedings of the SPE Improved Oil Recovery Symposium, SPE129767-MS, Tulsa, Okla, USA, April 2010. 
[12] K. K. Mohanty and S. Chandrasekhar, "Wettability alteration with brine composition in high temperature carbonate reservoirs," in Proceedings of the SPE Annual Technical Conference and Exhibition, SPE-166280-MS, New Orleans, Louis, USA, October 2013.

[13] Z. Yi and H. K. Sarma, "Improving waterflood recovery efficiency in carbonate reservoirs through salinity variations and ionic exchanges: a promising low-cost 'Smart-Waterflood' approach," in Proceedings of the Abu Dhabi International Petroleum Conference and Exhibition, SPE-161631-MS, Abu Dhabi, UAE, November 2012.

[14] T. Austad, S. Strand, E. J. Høgnesen, and P. Zhang, "Seawater as IOR fluid in fractured chalk," in Proceedings of the SPE International Symposium on Oilfield Chemistry, vol. 93000-MS of Society of Petroleum Engineers, pp. 193-202, The Woodlands, Tex, USA, February 2005.

[15] S. Strand, T. Austad, T. Puntervold, E. J. Høgnesen, M. Olsen, and S. M. F. Barstad, "'Smart Water' for oil recovery from fractured limestone: a preliminary study," Energy and Fuels, vol. 22, no. 5, pp. 3126-3133, 2008.

[16] J. Romanuka, J. Hofman, D. Jacob Ligthelm et al., "Low salinity EOR in carbonates," in Proceedings of the Low Salinity EOR in Carbonates, SPE-153869-MS, Tulsa, Oklahoma, USA, April 2012.

[17] A. A. Al Quraishi, S. N. Al Hussinan, and H. Q. Al Yami, "fficiency and recovery mechanisms of low salinity waterflooding in sandstone and carbonate reservoir," in Proceedings of the Offshore Mediterranean Conference and Exhibition, OMC-2015223, Ravenna, Italy, March 2015.

[18] A. Yousef et al., "Laboratory investigation of novel oil recovery method for carbonate reservoirs," in Proceedings of the Canadian Unconventional Resources and International Petroleum Conference, SPE-137634-MS, Calgary, Canada, October 2010.

[19] H. Mahani, A. L. Keya, S. Berg, W.-B. Bartels, R. Nasralla, and W. Rossen, "Driving mechanism of low salinity flooding in carbonate rocks," in Proceedings of the EUROPEC 2015, SPE174300-MS, Madrid, Spain, June 2015.

[20] R. A. Nasralla and H. A. Nasr-El-Din, "Double-layer expansion: is it a primary mechanism of improved oil recovery by lowsalinity waterflooding?" in Proceedings of the SPE Improved Oil Recovery Symposium, SPE-154334-MS, Tulsa, Okla, USA, April 2012.

[21] R. A. Nasralla and H. A. Nasr-El-Din, Double-Layer Expansion: Is It a Primary Mechanism of Improved Oil Recovery by LowSalinity Waterflooding?SPE-154334-PA, SPE Reservoir Evaluation \& Engineering, 2014.

[22] N. Kazankapov, "Enhanced oil recovery in Caspian carbonates with Smart Water," in Proceedings of the SPE Russian Oil and Gas Exploration and Production Technical Conference and Exhibition 2014, RO and G 2014-Sustaining and Optimising Production: Challenging the Limits with Technology, vol. SPE-171258-MS, pp. 1097-1113, Moscow, Russia, October 2014.

[23] Th. F. Tadros, Solid Liquid Dispersions, Academic Press, London, UK, 1987.

[24] P. McGuire, J. Chatham, F. Paskvan, D. Sommer, and F. Carini, "Low salinity oil recovery: an exciting new EOR opportunity for Alaska's North slope," in Proceedings of the SPE Western Regional Meeting, SPE-93903-MS, rvine, Calif, USA, April 2005.

[25] A. Lager, K. J. Webb, C. J. J. Black, M. Singleton, and K. S. Sorbie, "Low Salinity Oil Recovery-An Experimental Investigation1," Society of Petrophysicists and Well-Log Analysts, SPWLA2008-v49nla2, February 2008.
[26] E. J. Hognesen, S. Strand, and T. Austad, "Waterflooding of preferential oil wet carbonates: oil recovery related to reservoir temperature and brine composition," in Proceedings of the SPE EUROPEC/EAGE Annual Conference, SPE 94166, Madrid, Spain, 2005.

[27] A. Al Harrasi, R. S. Al-Maamari, and S. K. Masalmeh, "Laboratory investigation of smart waterflooding for carbonate reservoirs," in Proceedings of the Abu Dhabi International Petroleum Conference and Exhibition, SPE-161468-MS, Abu Dhabi, UAE, November 2012.

[28] H. H. Al-Attar, M. Y. Mahmoud, A. Y. Zekri, R. A. Almehaideb, and M. T. Ghannam, "Low salinity flooding in a selected carbonate reservoir: experimental approach," in Proceedings of the EAGE Annual Conference \& Exhibition incorporating SPE Europec, London, UK, June 2013.

[29] W. Alameri, T. W. Teklu, R. M. Graves, H. Kazemi, and A. M. AlSumaiti, "Wettability alteration during low-salinity waterflooding in carbonate reservoir cores," in Proceedings of the SPE Asia Pacific Oil \& Gas Conference and Exhibition, SPE171529-MS, Adelaide, Australia, October 2014.

[30] H. T. Kwak, A. A. Yousef, and S. Al-Saleh, "New insights on the role of multivalent ions in water-carbonate rock interactions," in Proceedings of the 19th SPE Improved Oil Recovery Symposium (IOR '14), SPE-169112-MS, pp. 1169-1186, Tulsa, Okla, USA, April 2014.

[31] H. O. Stern, "Zur theorie der elektrolytischen doppelschicht," Berichte der Bunsengesellschaft für physikalische Chemie, vol. 30, no. 21-22, pp. 508-516, 1924.

[32] A. Zahid, A. A. Shapiro, and A. Skauge, "Experimental studies of low salinity waterflooding carbonate: a new promising approach," in Proceedings of the SPE EOR Conference at Oil and Gas West Asia, SPE-155625-MS, Muscat, Oman, April 2012.

[33] A. Zahid, E. H. Stenby, and A. A. Shapiro, "Smart waterflooding (High Sal/Low Sal) in carbonate reservoirs," in Proceedings of the SPE Europec/EAGE Annual Conference, SPE-154508-MS, Copenhagen, Denmark, June 2012. 


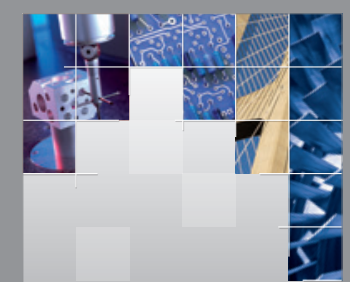

\section{Enfincering}
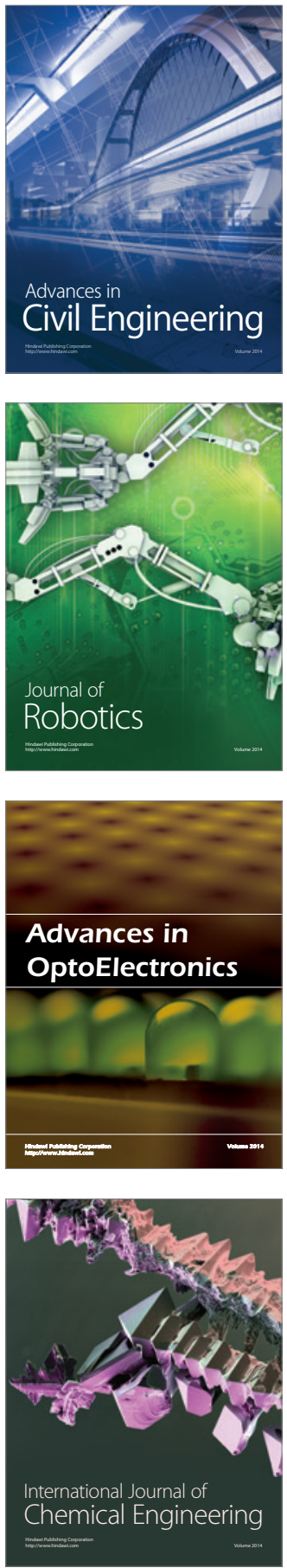

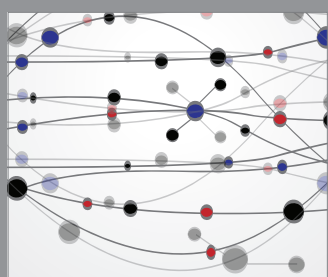

The Scientific World Journal

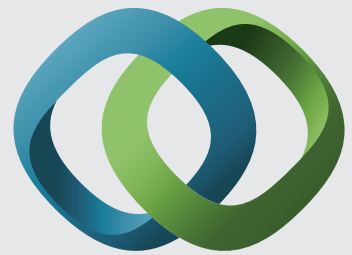

\section{Hindawi}

Submit your manuscripts at

https://www.hindawi.com
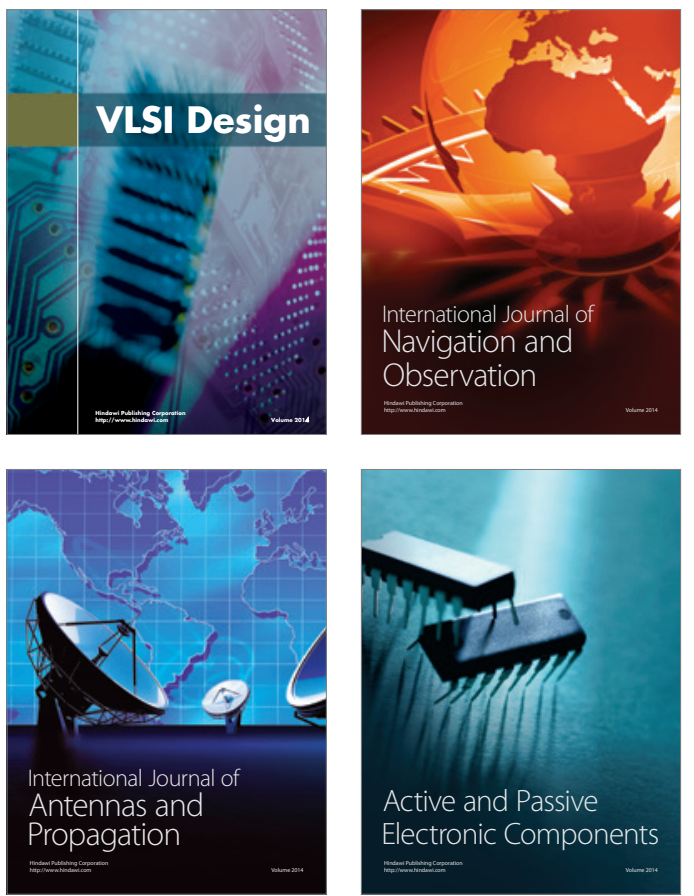
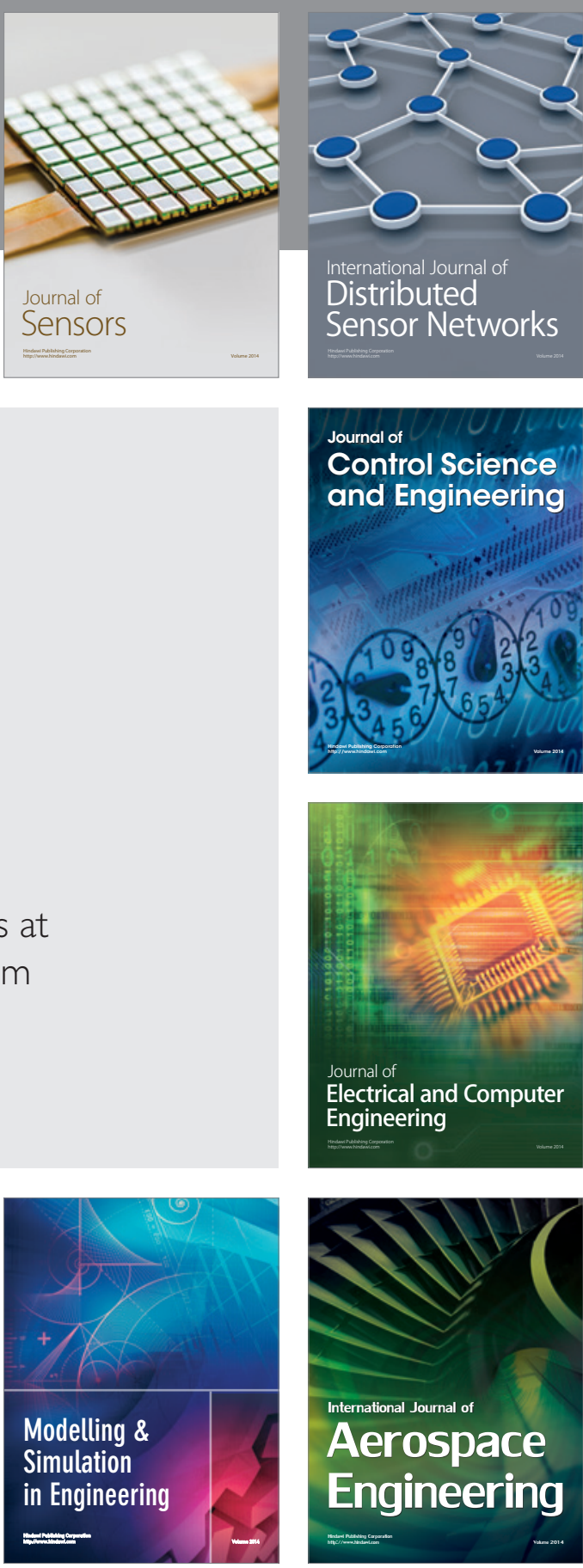

International Journal of

Distributed

Sensor Networks

$-$

Joumal of

Control Science

and Engineering
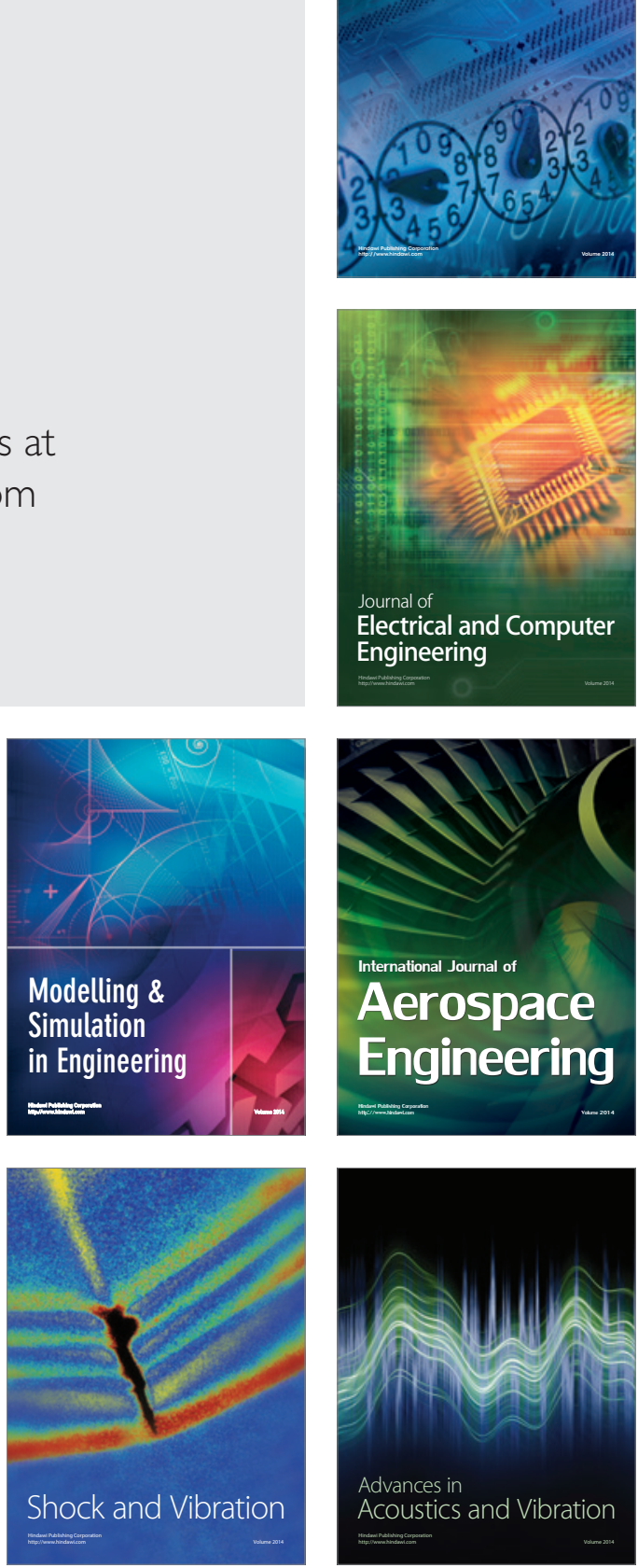